\title{
ANALISIS RASIO SOLVABILITAS TERHADAP KINERJA KEUANGAN PT GARUDA INDONESIA DI MASA PANDEMI
}

\author{
Cesira Desti Kinasih ${ }^{1}$, Firda Uswatun Nisa², Helsa Fikriyah ${ }^{3}$, Sarah Azzahra ${ }^{4}$ \\ ${ }^{1}$ Sarjana Akuntansi, Fakultas Ekonomi dan Bisnis, Universitas Islam Negeri Syarif Hidayatullah Jakarta \\ ${ }^{2}$ Sarjana Akuntansi, Fakultas Ekonomi dan Bisnis, Universitas Islam Negeri Syarif Hidayatullah Jakarta \\ ${ }^{3}$ Sarjana Akuntansi, Fakultas Ekonomi dan Bisnis, Universitas Islam Negeri Syarif Hidayatullah Jakarta \\ ${ }^{4}$ Sarjana Akuntansi, Fakultas Ekonomi dan Bisnis, Universitas Islam Negeri Syarif Hidayatullah Jakarta \\ cesira.destik19@mhs.uinjkt.ac.id ${ }^{1}$, firda.nisa19@mhs.uinjkt.ac.id ${ }^{2}$,helsa.fikriyah19@mhs.uinjkt.ac.id ${ }^{3}$, \\ sarah.azzahra19@mhs.uinjkt.ac.id ${ }^{4}$
}

\begin{abstract}
ABSTRAK
Penelitian yang ini bertujuan untuk mengetahui pengaruh solvabilitas terhadap kinerja keuangan PT Garuda Indonesia Tbk selama pandemi. Metode penelitian menggunakan data laporan keuangan selama periode 2017-2020. Penelitian yang kami lakukan menggunakan metode kuantitatif asosiatif yang dinyatakan dalam bentuk angka atau skala numerik untuk menentukan apakah perusahaan memiliki kemampuan untuk melunasi utang jangka panjangnya. Data tersebut kemudian kami uji menggunakan Debt to Asset Ratio (DAR) dan Debt to Equity Ratio (DER). Dalam penelitian ini, peneliti menemukan bahwa pandemi Covid-19 di Indonesia memiliki dampak yang sangat signifikan terhadap solvensi kinerja keuangan perusahaan PT Garuda Indonesia Tbk.
\end{abstract}

Kata Kunci: Kinerja Keuangan, Laporan Keuangan, Solvabilitas, Covid-19.

\section{ABSTRACT}

This study aims to examine the effect of solvability on the financial performance of PT Garuda Indonesia Tbk during the pandemic. The research method uses financial statement during the period 2017-2020. This research was conducted using the assosiative quantitative method expressed in the form of number or a numerical scale to determine whether the company has the capability to pay off its long term debt. We then tested the data using Debt to Asset Ratio (DAR) and Debt to Equity Ratio (DER). We find this investigation that Covid-19 in Indonesia have significant impact on the solvency of the company's financial performance.

Keywords: Financial Performance, Financial Statement, Solvability, Covid-19.

\section{A. PENDAhULUAN}

Jika dilihat dari perkembangan dunia usaha saat ini, hanya perusahaan unggul dan kompetitif yang dinilai dapat bertahan dalam dunia bisnis. Perusahaan harus mampu mempertahankan kinerja keuangan yang baik sehingga akan sangat memudahkan dalam mencari calon investor. Karena dengan kinerja keuangan yang baik calon investor akan sangat mudah dalam menilai apakah perusahaan tersebut dinilai layak untuk mendapatkan investor atau justru sebaliknya. Hal inilah yang harus diperhatikan perusahaan agar jangan 
sampai mengalami penurunan kinerja keuangan.

Hal terpenting dan menarik perhatian investor adalah Laporan Keuangan dari sebuah perusahaan. Dan yang paling penting adalah pada Laporan Laba Rugi atau yang biasa disebut dengan Income Statement, Laporan Neraca, dan laporan arus kas dari suatu perusahaan.

Ada beberapa jenis analisis yang biasanya digunakan oleh seorang investor dalam mempertimbangkan hasil kinerja suatu perusahaan. Rasio merupakan salah satu alat kinerja yang paling umum digunakan oleh manajer dalam kinerja perusahaannya Salah satunya dengan analisis rasio. Rasio ini dibagi menjadi lima kelompok, diantaranya :

(1). Rasio aktivitas, berfungsi untuk menghitung kinerja suatu perusahan dalam kemampuannya memanfaatkan kekayaan yang dimiliki.

(2). Rasio solvabilitas, berfungsi untuk menghitung kinerja suatu perusahaan dalam kemampuannya untuk melunasi liabilitas jangka panjang.

(3). Rasio profitabilitas, berfungsi untuk menghitung kemampuan perusahaan dalam memperoleh profit.

(4). Rasio likuiditas, berfungsi untuk kinerja suatu perusahaan dalam kemampuannya untuk melunasi liabilitas jangka pendek.

(5). Rasio pasar, berfungsi untuk memperoleh informasi-informasi penting mengenai saham dari suatu perusahaan.

Namun, dalam jurnal ini kami hanya akan membahas mengenai pengaruh rasio solvabilitas dalam laporan keuangan PT Garuda Indonesia Tbk pada periode 20172020. PT Garuda Indonesia Tbk ini termasuk bentuk perusahaan dalam bidang transportasi udara, di mana perusahaan ini milik negara yang dituntut untuk tetap menjaga kestabilan kinerja keuangannya. Perusahaan ini juga dituntut dalam meningkatkan kualitas pelayanan kepada penumpang, meningkatkan pemeliharaan armada, sehingga tingkat keselamatan penumpang pun terjamin.

\section{B. METODE}

\section{Jenis Penelitian}

Metode penelitian yang kami gunakan adalah metode kuantitatif asosiatif, di mana dalam metode penelitian ini dilakukan dengan cara mengaitkan dua variabel atau lebih untuk menganalisis hubungan antara variabel tersebut yang dinyatakan dalam bentuk angka atau skala numerik. Berdasarkan pada tujuan penelitian maka jenis penelitian yang digunakan adalah penelitian korelasi atau jenis penelitian yang melihat pengaruh antar varibel $\mathrm{X}$ (rasio solvabilitas) terhadap variable $\mathrm{Y} \quad$ (kinerja keuangan). Penelitian ini juga memberikan Analisa terhadap pengaruh yang ditimbulkan antar variable $\mathrm{X}$ dan $\mathrm{Y}$. Rasio Solvabilitas diperoleh dari catatan laporan keuangan PT Garuda Indonesia Tbk yang di terbitkan secara periodik. Dalam penelitian ini rasio solvabilitas diukur dengan 
menggunakan data keuangan tahun 2017-2020.

\section{Teknik Analisis Data}

Penelitian ini menggunakan data kuantitatif yang diperoleh dari dalam laporan keuangan pada PT Garuda Indonesia selama tahun 2017-2020. Data kuantitatif yakni pendekatan penelitian yang dimana didalamnya dominan penggunaan angka, meliputi pengumpulan data, penafsiran terhadap data yang diperoleh, dan juga pemaparan hasilnya (Arikunto, 2006).

\section{Variabel Data}

- Variabel Independen

Variabel independen dalam penelitian ini yaitu rasio solvabilitas. Rasio solvabilitas ini memberikan gambaran tentang kemampuan perusahaan dalam memenuhi kewajiban jangka panjangnya.

- Variabel Dependen

Variabel dependen dalam penelitian ini yaitu kinerja keuangan pada perusahaan PT Garuda Indonesia selama masa pandemic. Kinerja keuangan dapat diukur salah satunya dengan menggunakan rasio solvabilitas. Dengan rasio solvabilitas inilah perusahaan dapat dikatakan mampu atau tidaknya dalam memenuhi kewajiban jangka panjangnya.

\section{Metode Pengumpulan Data}

Metode pengumpulan data yang gunakan yaitu metode sekunder, di mana penelitian ini menganalisis data dari Bursa Efek Indonesia (BEI) dan website resmi PT Garuda Indonesia Tbk

\section{TINJAUAN PUSTAKA}

\section{Pengertian Laporan Keuangan}

Banyak penganalisis yang berpendapat bahwa dengan menggunakan laporan keuangan, mereka dapat menilai kinerja dan kondisi ekonomi suatu perusahaan. Laporan keuangan menggambarkan kondisi keuangan dan hasil usaha suatu perusahaan pada saat tertentu atau jangka tertentu (Harahap, 2013:105).

Laporan keuangan merupakan hasil dari suatu catatan yang diperoleh dari kegiatan informasi keuangan suatu periode akuntansi (biasanya satu tahun) yang menunjukkan kinerja atas perusahaan. Laporan Keuangan adalah catatan yang berisikan keadaan keuangan dari perusahaan pada masa sekarang atau pada periode yang lain. Jadi, laporan atau informasi yang berisi keuangan perusahaan serta kinerja perusahaan yang dapat membantu para pengguna laporan keuangan (yang berkepentingan) dalam menentukan keputusan.

\section{Tujuan Laporan Keuangan}

Laporan keuangan pada umumnya berfungsi untuk menyediakan informasi keuangan perusahaan yang akan bermanfaat bagi pihak yang membutuhkan atas informasi dari laporan keuangan tersebut. Bagi pihak internal, suatu laporan keuangan berfungsi untuk mengetahui kondisi atau keadaan perusahaan. Misalnya, 
manajemen perusahaan menggunakan laporan keuangan perusahaan sebagai acuan dalam merencanakan kegiatan yang akan dilakukan perusahaan di masa depan. Kemudian bagi pihak eksternal misalnya kreditor, laporan keuangan perusahaan berfungsi sebagai bahan acuan dan bahan pertimbangan untuk menolak ataupun menyetujui pinjaman yang diajukan.

Pada umumnya, laporan keuangan terbagi menjadi 5 jenis, yang dimana masing-masing jenisnya memiliki fungsi diantaranya :

a) Pada Statement of Financial Position, kita dapat mengetahui besaran aset, utang, serta ekuitas perusahaan dalam suatu periode.

b) Pada Income Statement, kita dapat mengetahui besarnya keuntungan ataupun kerugian yang didapatkan oleh perusahaan, dan juga kita bisa mengetahui besaran pendapatan dan beban perusahaan pada suatu periode.

c) Pada Statement of Cash Flow, kita dapat mengetahui besarnya aliran arus kas yang masuk dan juga aliran arus kas keluar perusahaan.

d) Pada Statement of Capital, kita dapat mengetahui naik atau turunnya ekuitas pada periode yang bersangkutan.

e) Pada Notes to Financial Statement (CALK), kita dapat memahami mengenai akun-akun yang terdapat di dalamnya.

\section{Manfaat Analisis Laporan Keuangan}

Bagi perusahaan, analisis laporan keuangan dapat menginformasikan bagianbagian rinci perusahaan secara eksplisit ataupun implisit. Kemudian dapat memahami suatu kondisi perusahaan dari struktur keuangan, kinerja, hasil usaha, dan sebagainya. Manfaat umum analisis laporan kuangan biasanya untuk menilai prestasi perusahaan, memprediksi potensi perusahaan yang ingin dilakukan dimasa mendatang, dan dapat menilai perubahan antara tahun-tahun sebelumnya.

Bagi pemerintah, manfaat analisis laporan keuangan dapat dijadikan sebagai acuan dalam menentukan besaran pajak yang harus dibayarkan oleh perusahaan kepada pemerintah. Selain itu pemerintah juga dapat mengetahui penggolongan jenis pajak apakah yang dipakai oleh perusahaan tersebut.

Bagi investor, dalam melakukan investasi atau penanaman modal di perusahaan, mereka melakukan analisis ataupun mengecek hasil kinerja keuangan dari perusahaan yang akan mereka tanamkan modalnya. Laporan keuangan yang dimiliki perusahaan sangat penting bagi investor karena dalam laporan tersebut berisi risiko atau hasil atas pencapaian kinerja perusahaan selama periode berjalan. Para pemegang saham pun juga akan melirik laporan keuangan perusahaan yang sehat atau rendah risiko yang berfungsi untuk 
melihat sejauh mana kemampuan perusahaan membayar dividen.

\section{Unsur Laporan Keuangan}

Unsur laporan keuangan berdasarkan PSAK demi mencapai kelengkapan terdiri dari, laporan laba rugi, laporan perubahan modal, laporan posisi keuangan (neraca), laporan arus kas, catatan atas laporan keuangan, dan laporan posisi keuangan komparatif pada periode awal.

\section{Analisis Laporan Keuangan}

Untuk menilai kinerja keuangan perusahaan, maka perlu dilakukan analisis terhadap laporan keuangan perusahaan, karena dengan adanya analisis laporan keuangan kita dapat mengetahui potensi keberhasilan perusahaan tersebut dalam mengelola keuangannya.

Analisis laporan keuangan adalah penilaian atas kondisi keuangan perusahaan yang sebenarnya (Dr. Kasmir). Analisis laporan keuangan biasanya bertujuan untuk mengetahui dan menilai kinerja perusahaan, serta untuk mengetahui aspek mana yang harus diperbaiki atau dingkatkan. Analisis laporan keuangan juga dilakukan untuk membandingkan kinerja dan pencapaian periode sebelumnya dengan periode saat ini.

Analisis laporan keuangan biasanya dilakukan untuk :

1. Menjadi salah satu alat yang digunakan dalam penyaringan awal yang menjadi alternative dalam menyeleksi saham, yang memberikan ramalan mengenai kondisi keuangan perusahaan.

2. Sebagai alat prediksi kondisi keuangan perusahaan di masa depan. Analisis laporan keuangan saat ini menjadi hal yang paling penting dalm memperkirakan kondisi perusahaan di masa mendatang. Apabila terjadi banyak kekurangan pada saat ini, perusahaan dapat memperbaiki agar kesalahan tersebut terulang kembali.

3. Sebagai alat identifikasi dalam masalah-masalah yang terjadi pada kegiatan manajemen maupun kegiatan operasi. Hasil dari identifikasi dari laporan keuangan harus mampu memperediksi tingkat keberhasilan dan kegagalan suatu perusahaan pada suatu periode. Hasil yang kurang baik sebaiknya diperbaiki agar di masa mendatang tidak ada lagi kegagalan yang terjadi.

4. Sebagai penilaian kembali terhadap kegiatan manajemen. Laporan keuangan harus bisa menjadi evaluasi terhadap kegiatan manajemen apabila terjadi hal-hal yang tidak diinginkan perusahaan, karena peran manajemen sangat penting dalam menentukan 
keputusan. Maka manajemen harus berhati-hati dalam mengambil tindakan agar ke depannya setiap keputusan yang diambil oleh manajemen dapat dipertimbangkan dengan matang dan bertanggung jawab atas keputusan yang diambil.

\section{a. Pengertian Rasio Keuangan}

Rasio keuangan yaitu suatu aktivitas yang didalamnya menyajikan perbandingan angka yang terdapat di dalam laporan keuangan, yang dimana untuk setiap jenis perhitungan rasio memiliki standar yang berbeda. Secara umum rasio keuangan ada 4 , yaitu :

(a). Rasio Likuiditas yaitu rasio yang berfungsi untuk mengetahui kemampuan perusahaan dalam melunasi utang jangka pendeknya.

\section{Current Ratio (Rasio Lancar)}

2. Quick Ratio (Rasio Cepat)

3. Cash Ratio (Rasio Kas)

(b). Rasio Aktivitas merupakan rasio yang berfungsi dalam menentukan tingkat aktivitas aktiva pada tingkat kegiatan tertentu.

1. Rasio keuangan perputaran piutang

2. Rasio perputaran persediaan

3. Rasio keuangan perputaran aktiva tetap

4. Rasio perputaran total aktiva (c). Rasio Profitabilitas merupakan rasio yang mengukur seberapa besar profit yang akan diperoleh perusahaan.

1. Gross Profit Margin

2. Operating Profit Margin

3. Net Profit Margin

4. Return on Assets

5. Return on Investment

(d). Rasio pasar, rasio ini memberitahu mengenai informasi saham yang dimiliki perusahaan dalam menunjang kegiatannya.

1. Price Earning Ratio (PER)

2. Dividen Yield

(e). Rasio Solvabilitas merupakan rasio yang mengukur kemampuan perusahaan dalam melunasi semua liabilitasnya.

1. Debt to Assets Ratio

2. Debt to Equity Ratio

Dalam penilitian kami ini, kami hanya membahas analisis rasio solvabilitas.

\section{b. Analisis Rasio Keuangan}

Analisis rasio keuangan memberikan memprioritaskan terhadap perhitungan rasio yang biasanya digunakan dalam pengevaluasian terhadap laporan keuangan suatu perusahaan di masa yang telah berlalu, pada masa sekarang, maupun di masa mendatang.

Penggunaan rasio sangat penting dalam melakukan proses analisis. Biasanya perusahaan menggunakan rasio agar mudah dipahami dan pengerjaannya lebih rinci. 
Penggunaan rasio ini dalam menganalisis juga harus dapat mengetahui bagaimana perkembangan dan proses yang dijalani oleh perusahaan dalam suatu periode.

Analisis rasio keuangan merupakan alat yang di dalamnya berupa perhitungan dan angkaangka yang memuat gambaran mengenai laporan keuangan yang diberikan kepada pemangku kepentingan agar dapat mengetahui tentang baik maupun buruknya keadaan perusahaan (S, Munawir : 2002).

Jika suatu perusahaan memiliki aktiva yang cukup dan melebihi utangnya, sehingga memiliki kemampuan untuk menutupi utangutang tersebut, maka perusahaan ini dinilai solvable. Begitu pula jika perusahaan tidak memiliki cukup aktiva, sehingga liabilitasnya lebih besar, perusahaan ini berada pada kondisi insolvable.

\section{Debt to Asset Ratio}

Bagi pihak perusahaan pastinya lebih menyukai rasio yang semakin besar, karena pada dasarnya perusahaan mendapatkan kredit yang jumlahnya lebih banyak daripada asset yang dimiliki. Tetapi berbanding terbalik, mayoritas kreditur lebih menyukai rasio utang yang lebih rendah. Seperti yang kita ketahui, semakin rendah utang dan semakin tingginya asset, maka rasio pun akan semakin rendah, yang mengakibatkan perusahaan ini semakin mampu dalam memenuhi kewajibannya. Selain itu pula, para pemegang saham lebih membutuhkan leverage yang diniliai dapat memperbesar laba yang diharapkan.

Debt to Asset Ratio memiliki fungsi dalam mengukur besarnya jumlah asset yang dibiayai oleh utang.

Debt to Asset Ratio

2. Debt to Equity Ratio

$$
=\frac{\text { Total Liabilities }}{\text { Total Assets }} \times 100 \%
$$

Sama halnya dengan rasio utang terhadap asset, perusahaan akan lebih menyukai rasio yang semakin besar, karena dengan rasio yang semakin besar menunjukkan bahwa perusahaan dibiayai oleh utang atau kreditur mempercayai perusahaan tersebut, yang dimana hal tersebut berarti perusahaan masih dapat dipercayai oleh para kreditur untuk memperoleh dana pinjaman.

Debt to Equity Ratio atau biasa disebut dengan rasio utang modal memiliki fungsi dalam mengukur besaran utang dengan modal yang dimiliki.

Debt to Equity Ratio

$$
=\frac{\text { Total Liabilities }}{\text { Total Equity }} \times 100 \%
$$

Setiap komponen dalam rasio solvabilitas memiliki standar industri tersendiri (Dr. Kasmir, 2016), yang disajikan pada tabel dibawah ini : 


\begin{tabular}{ccc} 
Tabel 1. Standar Industri Rasio Solvabilitas \\
\hline Jenis Ratio & $\begin{array}{c}\text { Debt to } \\
\text { Asset } \\
\text { Ratio }\end{array}$ & $\begin{array}{c}\text { Debt to } \\
\text { Equity } \\
\text { Ratio }\end{array}$ \\
\hline Standar Industri & $35 \%$ & $90 \%$ \\
\hline
\end{tabular}

\section{Definisi Kinerja Keuangan}

Secara Universal kinerja keuangan ialah cerminan tentang keadaan keuangan suatu perusahaan yang dinilai dengan alat- alat analisis keuangan, sehingga terdapat baik dan buruknya kondisi keuangan suatu perusahaan yang mencerminkan keberhasilannya dalam menggapai tujuan.

Bagi Munawir (2010: 30) kinerja keuangan ialah satu diantara dasar evaluasi yang menimpa keadaan keuangan perusahaan yang bersumber pada analisa rasio keuangan perusahaan.

Fahmi (2012: 2) berpendapat bahwa kinerja keuangan merupakan suatu analisis yang memandang sepanjang mana suatu perusahaan sudah menerapkan aturan- aturan keuangan secara baik serta benar. Kinerja perusahaan juga mencerminkan tentang keadaan keuangan perusahaan yang dianalisis dengan rasio analisis keuangan, sehingga bisa dilihat baik buruknya kondisi keuangan atas suatu prestasi dalam suatu tahun tertentu.

Setelah itu, Jumingan (2011: 239) berpendapat bahwa kinerja keuangan ialah cerminan keadaan keuangan pada suatu kurun waktu tertentu yang menyangkut aspek penghimpunan ataupun penyaluran dana yang umumnya diukur dengan profitabilitas, likuiditas, dan indikator kecukupan modal.

7. Tujuan dan Manfaat Kinerja Keuangan

Kinerja keuangan diukur dengan tujuan untuk melaksanakan pembetulan aktivitas opersionalnya sehingga mampu bersaing dalam dunia bisnis. Kemudian analisis kinerja keuangan ialah proses penelaahan ulang secara kritis terhadap data, mengukur bahkan menghitung, dan memberikan pemecahan terhadap keuangan perusahaan dalam kurun waktu tertentu.

Munawir $(2012 ; 31)$ berpendapat bahwa pengukuran kinerja keuangan memiliki tujuan untuk mengenali tingkatan likuiditas, solvabilitas, rentabilitas, bahkan tingkat stabilitasnya. 


\section{Analisis Kinerja Keuangan}

Kinerja keuangan dievaluasi untuk memutuskan sepanjang mana keberhasilan atas kinerja tersebut bisa menggapai sesuatu tujuan tertentu. Terdapat dua aspek yang kerap digunakan dalam memperhitungkan kinerja merupakan daya guna serta efensiensi. Daya guna mencerminkan ikatan output dengan tujuan tertentu, sebaliknya efesiensi menggambarkan ikatan input serta output.

\section{Kerangka pikir}

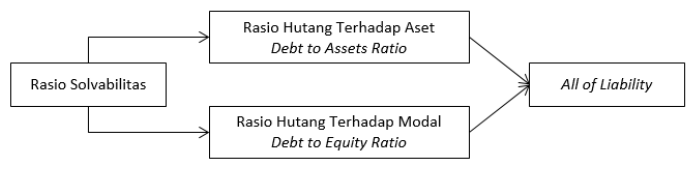

Gambar 1. Kerangka pikir

Sumber : Hasil kajian teori

Rasio solvabilitas memiliki tujuan yaitu agar dapat mengetahui posisi perusahaan dengan kewajiban yang dimilikinya, untuk mengetahui besarnya aktiva yang dibiayai oleh utang, dan dapat mengetahui kemampuan perusahaan dalam membayar semua utangnya.

(Agus Sartono, 2001:120) ada 3 jenis dimensi yang biasa digunakan dalam penggunaan utang, yaitu :

1. Kreditur biasanya akan memprioritaskan terhadap besarnya jaminan atas kredit yang diserahkan.

2. Dengan utang yang telah diterbitkan oleh suatu perusahaan maka perusahaan akan dengan mudah mendapatkan keuntungan sehingga keuntungan yang dimiliki perusahaan akan meningkat lebih besar.

3. Dengan adanya utang pula pemilik akan memperoleh pengendalian atas perusahaannya dan tidak akan kehilangan atas pengendalian tersebut

D. HASIL DAN PEMBAHASAN

Tabel 2. Hasil Perhitungan Rasio Solvabilitas Debt to Asset Ratio

\begin{tabular}{ccccccc}
\hline Tahun & \multicolumn{2}{c}{ Total Utang } & \multicolumn{2}{c}{ Total Aset } & Selisih & $\%$ \\
\hline 2017 & USD & 2.825 .822 .893 & USD & 3.763 .292 .093 & 0,7509 & 75,09 \\
\hline 2018 & USD & 3.515 .668 .247 & USD & 4.155 .474 .803 & 0,8460 & 84,60
\end{tabular}




\begin{tabular}{rrrrrrr}
\hline 2019 & USD & 3.735 .052 .883 & USD & 4.455 .675 .774 & 0,8383 & 83,83 \\
\hline 2020 & USD & 10.361 .096 .065 & USD & 9.905 .520 .965 & 1,0460 & 104,60 \\
\hline
\end{tabular}

Debt to Equity Ratio

\begin{tabular}{rrrrrrr}
\hline Tahun & \multicolumn{2}{c}{ Total Utang } & \multicolumn{2}{c}{ Total Ekuitas } & \multicolumn{1}{c}{ Selisih } & \multicolumn{1}{c}{$\%$} \\
\hline 2017 & USD & 2.825 .822 .893 & USD & 937.469 .200 & 3,014 & 301,43 \\
\hline 2018 & USD & 3.515 .668 .247 & USD & 639.806 .556 & 5,495 & 549,49 \\
\hline 2019 & USD & 3.735 .052 .883 & USD & 720.622 .891 & 5,183 & 518,31 \\
\hline 2020 & USD & 10.361 .096 .065 & -USD & 455.575 .100 & $-22,743$ & $-2274,29$ \\
\hline
\end{tabular}

Sumber data diolah pada tahun 2021

\section{- Debt to Asset Ratio}

Pada tabel tersebut, memperlihatkan rasio yang berfluktuasi. Pada tahun 2017 menghasilkan nilai rasio $75,09 \%$ yang kemudian meningkat di tahun 2018 sebesar 9,51 dengan nilai rasio menjadi $84,60 \%$. Kemudian terjadi sedikit penurunan pada tahun 2019 sebesar 0,77 menjadi 83,83\%. Peningkatan yang signifikan terjadi pada tahun 2020 sebesar 20,77 menjadi $104,60 \%$. Untuk keempat tahun tersebut ternyata jauh diatas rata-rata nilai industri (35\%) yang menyebabkan perusahaan di nilai kurang baik dalam pengelolaan kinerja keuangan. Nilai DAR periode 2020 mengalami kenaikan yang cukup signifikan daripada periode yang telah berlalu. Hal tersebut dapat menyulitkan perusahaan dalam memperoleh pinjaman terlebih pada tahun terakhir PT Garuda Indonesia sepenuhnya di biayai oleh utang.

\section{- Debt to Equity Ratio}

Sama seperti analisis sebelumnya, DER menunjukkan rasio yang berfluktuasi pada tiap tahunnya. Tahun 2017 menghasilkan rasio $301,43 \%$ dan kemudian meningkat jauh sebesar 248,06 menjadi $549,49 \%$ di tahun 2018. Lalu terjadi sedikit penurunan pada tahun 2019 sebesar 31,18 menjadi 518,31\%. Pada tahun 2020 ternyata nilai DER mengalami keanjlokan sebesar 2.792,8 menjadi $-2.274,29 \%$. Dimana hal tersebut menunjukkan bahwa DER pada PT Garuda Indonesia sangat jauh dari standar industri (90\%), sama seperti halnya pada Debt to Asset Ratio semakin jauh rasio tersebut dari rata-rata standar industri, maka semakin buruk perusahaan dalam mengelola kinerja keuangannya. Hal ini dapat menyebabkan perusahaan akan sangat sulit untuk mendapatkan pinjaman, dikarenakan pada sisi DER perusahaan sepenuhnya juga di biayai oleh utang.

\section{E. PENUTUP}

\section{Kesimpulan}

Kesimpulan yang dapat dari hasil penelitian tersebut, menyatakan bahwa analisis terhadap rasio solvabilitas yang di proksikan dengan Debt to Assets Ratio, perusahaan mengalami fluktuasi pada setiap tahun dan dinilai jauh di atas rata-rata 
industri yang diungkapkan oleh Kasmir yaitu sebesar 35\%. Jika dilihat dari perhitungan rata-rata industri PT Garuda Indonesia, perusahaan menghasilkan nilai yang sangat jauh. Hal tersebut mengartikan bahwa perusahaan kurang baik dalam mengelola kinerja keuangan terlebih pada setiap tahunnya total utang pun mengalami kenaikan yang cukup signifikan. Begitu pula halnya Debt to Equity Ratio menunjukan persentase yang sama dengan Debt to Assets Ratio, dimana DER ini menunjukkan rasio yang berfluktuasi dan telah mencapai bahkan melebihi standar industri yang dikemukakan oleh Kasmir yaitu sebesar $90 \%$.

Di tahun 2020, nilai DAR mengalami kenaikan angka yang sangat drastis. Sedangkan, untuk nilai DER mengalami penurunan yang sangat jauh sehingga angka tersebut mencapai minus. Hal tersebut berkaitan erat dengan terjadinya Pandemi Covid-19 yang berdampak banyak pada perekonomian di berbagai negara dari belahan dunia termasuk salah satunya perekonomian di Indonesia. Menurut Estro Daratno Sihaloho pada Konferensi Pers, tertanggal 1 April, Kementrian Keuangan menyebutkan bahwa terdapat ancaman terhadap penurunan pendapatan bahkan kehilangan pendapatan (pekerjaan) terutama bagi masyarakat yang memiliki pekerjaan informal atau pekerjaan tidak tetap.

Dampak berikutnya adalah ancaman terhadap penutupan seluruh jasa transportasi termasuk pada sektor penerbangan. Salah satu maskapai yang sangat merasakan dampak adanya Pandemi Covid-19 adalah maskapai penerbangan PT Garuda Indonesia Tbk. Artinya, dengan ditutupnya semua sektor penerbangan maka akan menyebabkan penurunan pendapatan PT Garuda Indonesia Tbk. Sedangkan PT Garuda Indonesia sendiri memiliki karyawan yang banyak dan pastinya akan membutuhkan biaya yang cukup besar untuk hal tersebut. Belum lagi dengan biaya untuk pemeliharaan pesawat yang juga membutuhkan dana yang tidak sedikit. Jadi wajar saja jika memang perusahaan mengalami pembengkakan terhadap hutang.

Jika hal ini terjadi terus-menerus, maka PT Garuda Indonesia diprediksi akan mengalami financial distress, yang merupakan keadaan suatu perusahaan di mana arus kasnya tidak mampu untuk menutupi atau melunasi kewajibankewajiban yang ada. Financial distress merupakan kondisi perusahaan yang mengalami kebangkrutan akibat dari kerugian-kerugian dalam beberapa tahun. Maka diperlukan perbaikan yang harus dilakukan PT Garuda Indonesia TBK, misalnya seperti perluasan dan pencarian modal saham, pengurangan karyawan yang dilakukan dalam rangka melakukan penekanan terhadap pengeluaran, melakukan restrukturisasi kredit terhadap hutang yang dimiliki PT Garuda Indonesia dan 
yang paling penting adalah peningkatan terhadap pendapatan. PT Garuda Indonesia harus dengan tanggap memikirkan bagaimana cara untuk membangkitkan perusahaan serta meningkatkan pendapatan perusahaan.

\section{Saran}

(a). Perusahaan sebaiknya melakukan restrukturisasi kredit terhadap hutang yang dimiliki agar prediksi terhadap financial distress tidak terjadi. Restrukturisasi kredit ini dapat dilakukan dengan melakukan perbaikan terhadap kredit yang dimiliki. Dapat berupa pengecilan bunga dan pembayaran kredit atau dengan perpanjangan masa kredit.

(b). Berdasarkan adanya penelitian yang telah kami lakukan pada PT Garuda Indonesia, kami hanya menggunakan menggunakan rasio solvabilitas saja. Jadi belum adanya analisis secara keseluruhan yang mendeskripsikan kondisi saat ini maupun sebelumnya yang lebih rinci. Untuk itu, kepada peneliti selanjutnya diharapkan melengkapi analisis rasio lainnya dan menambahkan periode terbaru yang lebih kompleks sehingga dapat mendeskripsikan tentang fluktuasi rasio pada kondisi perusahaan yang sesungguhnya.

(c). Menghentikan untuk sementara kegiatan penerbangan pada rute-rute tertentu yang sekiranya hanya memberikan sedikit atau bahkan tidak memberikan keuntungan, serta dapat menyebabkan semakin meluasnya wabah Covid-19.

(d). Apabila Pandemi Covid-19 ini sudah berlalu. Salah satu strategi untuk meningkatkan pendapatan masuk PT Garuda Indonesia dalam menarik minat para calon penumpangnya yaitu memberikan promo atau diskon atas penjualan tiketnya.

\section{DAFTAR PUSTAKA}

Agustin, A. L., Darminto, \& Handayani, S. R. (2013). Analisis Rasio Keuangan untuk Menilai Kinerja Keuangan Perusahaan (Studi pada Perusahaan Seman yang Terdaftar di BEI Periode 2009-2011. Jurnal Administrasi Bisnis (JAB), 2(1), 1-8.

Agustin, E. (2016). Analisis Rasio Keuangan untuk Penilaian Kinerja Keuangan pada PT. Indofarma (persero) Tbk. (Berdasarkan Keputusan Menteri BUMN Nomor :KEP100/MBU/2002). Jurnal IImu \& Riset Manajemen, 5(7), 103-115.

Akubis, J. (2017). Gregorius Kirene 1), Silvia Indrarini 2), Suprapti 3). Jurnal Akuntansi Dan Bisnis, 2, 29-37.

Barus, M., Sudjana, N., \& Sulasmiyati, S. (2017). PENGGUNAAN RASIO KEUANGAN UNTUK MENGUKUR KINERJA KEUANGAN PERUSAHAAN (Studi pada PT. Astra Otoparts, Tbk dan PT. Goodyer Indonesia, 
Tbk yang Go Public di Bursa Efek Indonesia). Jurnal Administrasi Bisnis S1 Universitas Brawijaya, 44(1), 154-163.

Ekonomi, F., Ekonomi, F., \& Ekonomi, F. (2019). Analisa Kinerja Keuangan pada PT. Garuda Indonesia,Tbk Reina Damayanti 1 , Hendry Saladin 2 , Juni Darwin 3 1. Jurnal Media Wahana Ekonomika, 15, 75-89.

Ekonomi, F., Samudra, U., \& On, R. (2017). Analisis Kinerja Keuangan PT. Garuda Indonesia Tbk Muhammad Rizal 1 1). Serambi Ekonomi Dan Bisnis, 4(March 2017), 1-10.

Faisal, A., Samben, R., \& Pattisahusiwa, S. (2018). Analisis kinerja keuangan. Kinerja, 14(1), 6. https://doi.org/10.29264/jkin.v14i1.2444

Kafi, M. S. (2018). Analisis Rasio Likuiditas, Rentabilitas Dan Solvabilitas Untuk Mengukur Kinerja Keuangan. JMK (Jurnal Manajemen Dan Kewirausahaan), 3(38), 49-60.

Kartawidjaja, J. (2020). Analisis Pengaruh Rasio Likuiditas dan Solvabilitas Terhadap Profitabilitas Pasa PT Garuda Indonesia. Orphanet Journal of Rare Diseases, 21(1), $1-9$.

Maith, H. A. (2013). Analisis Laporan Keuangan Dalam Mengukur Kinerja Keuangan Pada Pt. Hanjaya Mandala Sampoerna Tbk. Jurnal Riset Ekonomi, Manajemen, Bisnis Dan Akuntansi, 1(3), 619-628. https://doi.org/10.35794/emba.v1i3.2130
Orniati, Y. (2009). Laporan Keuangan sebagai Alat untuk Menilai Kinerja Keuangan. Jurnal Ekonomi Bisnis, 14(03), 206.

Pratiwi, H., \& Rodhiyah. (2016). Analisis Pengaruh Rasio Solvabilitas dan Rasio Likuiditas Terhadap Pertumbuhan Laba Pada Perusahaan Sub Sektor Perdagangan Besar yang Terdaftar di Bursa Efek Indonesia Periode 2014 - 2016 melakukan investasi terhadap sebuah perusahaan . Dengan pertumbuhan. Administrasi Bisnis, $1-11$.

Shahreza, D. (2017). Analisis Rasio Keuangan untuk Mengukur Tingkat Ksesehatan Keuangan di PT Garuda Indonesia (Persero) Tbk. JABE (Journal of Applied Business and Economic), 3(1),

35. https://doi.org/10.30998/jabe.v3i1.1756

Shintia, N. (2017). Analisis Rasio Solvabilitas Untuk Menilai Kinerja Keuangan Terhadap Asset dan Equity Pada PT Bank Rakyat Indonesia (PERSERO) Tbk Periode 20122015. At-Tadbir: Jurnal IImiah Manajemen, 1(1), 44-49.

Sugiyanto, V. Y. (2016). ANALISIS KINERJA KEUANGAN SEBELUM DAN SESUDAH GO PUBLIC PADA PT. GARUDA INDONESIA TBK TAHUN 2007-2014 Vivi Yanty Sugianto 1. Jurnal Bisnis Dan Manajemen, 52, 81-91.

Supeni, R. E., \& Hafdi, A. H. (2018). Kajian Empiris Restrukturisasi Keuangan Dan Pengaruhnya Terhadap Kinerja Pt . Garuda Indonesia. 1-14. 
Widiyanti, M. (2014). ANALISIS RASIO LIKUIDITAS, RASIO SOLVABILITAS, RASIO AKTIFITAS DAN RASIO PROFITABILITAS PADA PT. HOLCIM INDONESIA, Tbk DAN PT. INDOCEMENT TUNGGAL PRAKARSA, Tbk. Jembatan, 11(1), 31-44. https://doi.org/10.29259/jmbt.v11i1.3132 